\title{
MICHAEL THE SYRIAN AS A SOURCE FOR ECONOMIC HISTORY
}

\author{
MiChAEL G. MORONY \\ UNIVERSITY OF CALIFORNIA, LOS ANGELES \\ DEPARTMENT OF HISTORY \\ LOS ANGELES \\ CALIFORNIA
}

\begin{abstract}
The economic information in the universal bistory of the Syrian Orthodox Patriarch, Michael the Syrian (1166-99), is analyzed and evaluated. It is shown that most of his information concerns conditions that affected agricultural production, livestock, the labor force, and commerce in the Jazira and northern Syria from the sixth through the twelfth century C.E. The factors that reduced production are discussed, such as drought, freezing weather, hailstorms, and plagues of locusts as well as the effects of plague and famine on labor. The circumstances of rural labor, property and wealth are examined as well as the insecurity of merchants. It is argued that much of Michael's incidental economic information needs to be contextualized and compared to that in other sources.
\end{abstract}

[1] Claude Cahen, in a famous article, analyzed economic conditions in the Jazira in the third quarter of the eighth century C.E. based on 
information in the Syriac Chronicle of Zuqnin. ${ }^{1}$ In partial homage to his work the object here is to evaluate the economic information contained in the monumental universal history of the Syrian Orthodox Patriarch, Michael the Syrian (1166-99). ${ }^{2}$ Most of this information concerns conditions affecting agricultural production, livestock, the labor force, property, and commerce in the Jazira and northern Syria from the sixth through the twelfth century.

Michael mainly has information for the dry farming region in northern Syria and the Jazira, including the upper Euphrates and Tigris watersheds. This region depends on winter rainfall brought by westerlies from the Atlantic across the Mediterranean to western Asia and the Iranian plateau as far as the mountains of Central Asia. This weather system provides progressively less rainfall the further east one goes. Hypothetically one could use what Michael says about droughts and their effects to extrapolate conditions both to the east and to the west. Sometimes he notes that such conditions were more widespread. The Chronicle of Zuqnin confirms that rain usually fell in the winter, from October to the end of May, ${ }^{3}$ and that crops had usually ripened by May. ${ }^{4}$

The agrarian economy was based on cereal grains (wheat and barley), grapevines, and olive trees, but Michael says hardly anything about normal production levels. He has much more to say about abnormal conditions that reduced production and caused famines and economic distress. Agricultural production was reduced by drought, snow, ice, frost, violent winds, hail storms, and plagues of locusts. Sometimes there was too much rain at the

${ }^{1}$ Claude Cahen, "Fiscalité, propriété, antagonismes sociaux en HauteMésopotamie au temps des premiers 'Abbasides d'après Denys de TellMahré," Arabica, 1 (1954): 136-52.

${ }^{2}$ This study is based on the edition and translation by J.-B. Chabot, Chronique de Michel le Syrien (Paris: E. Leroux, 1899; repr. Bruxelles: Culture et Civilisation, 1963). The Syriac text is in volume four.

${ }^{3}$ J.-B. Chabot, Chronique de Denys de Tell-Mabré, Quatrieme Partie, Bibl. Éc/Hautes Études, 112 (Paris: Bibliotheque de l'École, 1895), 145 [175], 159 [192]; Amir Harrak, The Chronicle of Zuqnin, Parts III and IV, A.D. 488775 (Toronto: Pontifical Institute of Mediaeval Studies, 1999) 274, 288. The Chronique edited and translated by Chabot is the text of Part IV of the Chronicle of Zuqnin, which is an independent source from the actual Chronicle of Dionysius of Tell Mahre used by Michael.

${ }^{4}$ Chabot, Chronique de Denys, 101 [120]; Harrak, Chronicle of Zuqnin, 232. 
wrong time. Freezing weather meant that there was no liquid water for people or animals to drink or for crops until the ice and snow melted. Presumably it took longer to recover from damage to grapevines and olive and other fruit trees than from damage to grain crops. Mortality from plagues and famines could cause crops to go unharvested. The consequences of crop failure were rising food prices, famine, the abandonment of farms and villages, and emigration. ${ }^{5}$

Whatever the immediate effects were, extreme variability in agricultural production from one year to the next was a fact of life that needs to be set against long term trends such as reinvestment in grapevines and olive trees, and the development of irrigation and of cash crops other than grapes and olives. Simeon of the Olives is said to have planted 12,000 olive trees at his monastery on Tur 'Abdin before 700. They began to bear after five years, and the olive oil produced at his monastery provided all the churches and monasteries of Tur ${ }^{\text {Abdin }}$ with oil. ${ }^{6}$ Michael says that when Hanania, bishop of Marde and Kephar Touta from 793, founded a monastery near Marde, he planted grapevines and olive trees there. ${ }^{7}$ Michael also notes an uncompleted canal project under Yazid ibn Muawiya, ${ }^{8}$ and the more successful project under Hisham, who brought canals from the Euphrates below Callinicus to irrigate crops and plantations, the revenue from which was greater than the taxes from his entire empire. ${ }^{9}$ When Harun built Rafiqa in 790, he brought irrigation canals from the Euphrates and from Saruj and developed numerous gardens on their banks, ${ }^{10}$ and, when al-Mu'tașim built Samarra', he brought canals from the Tigris,

${ }^{5}$ Miquel Barceló, "Les plagues de llagost a la Carpetània," Estudis d'Història Agrària 1 (1978): 76 notes that drought and plagues make it impossible to maintain minimum levels of consumption over long periods with the demographic consequences of mortality and/or emigration.

${ }^{6}$ S.P. Brock, "The Fenqitho of the Monastery of Mar Gabriel in Tur "Abdin," Ostkirchliche Studien 28 (1979): 175-6.

${ }^{7}$ Michael the Syrian, Chronique, III, 20, IV, 489.

${ }^{8}$ Ibid., II, 470, IV, 446.

${ }^{9}$ Ibid., II, 490, IV, 457. Evidently one should allow for exaggeration in both the extent of development and the consequences of disasters. The Chronicle of Zuqnin (Chabot, Chronique de Denys, 23-4 [26]; Harrak, Cbronicle of Zuqnin, 160-1) gives more specific information about the irrigation projects of Hisham and his brother, Maslama, in this region.

${ }^{10}$ Michael the Syrian, Chronique, III, 10, IV, 493. 
planted groves, gardens, and palm trees, and brought balsam and rushes from Egypt to make paper and planted them on the banks of the canals. ${ }^{11}$ In about 1001-3 Marouta, the son of Elishe, a merchant of Tagrit, built a cistern for the monastery of Bar Gagai, that irrigated the vegetables of the monks. ${ }^{12}$ Irrigation canals certainly increased the land under cultivation and thereby agricultural production, but, since the canals were drawn from the Tigris and Euphrates rivers, they depended ultimately on rainfall upstream. As far as new crops are concerned, Michael's earliest reference to cotton in the Jazira is in $842 ; 1^{13}$ in 1134 he mentions cotton and sesame fields in the region of Edessa. ${ }^{14}$

With regard to the effects of natural disasters on agricultural production, it is evident from the Chronicle of Zuqnin and other contemporary sources that there are gaps in Michael's information about severe weather, droughts, plagues of locusts, and famine for the same region. Thus the lack of a reference by Michael to such events in a particular year cannot be taken to mean that all was well. ${ }^{15}$ Both Michael and the Chronicle of Zuqnin based their accounts of much of the sixth century on John of Ephesus, but only the Chronicle of Zuqnin notes the severe winter of 528-9 and that wheat fields from Syria to Thrace went unharvested during the plague of 543-4, or notes the eight-year famine at Amida and its territory from 546 to 554 caused by crop failure and the flood that ruined vineyards at Tarsus in 549-50.16

Michael also used the Chronicle of Dionysius of Tell Mahre, the Syrian Orthodox Patriarch (818-45), who began his Secular History with the reign of Maurice in 582. This is probably why Michael begins to mention disasters that affected agriculture in 600 , a year of drought and strong wind throughout Syria and Palestine, when olives and other trees withered. ${ }^{17}$ Snow and cold, such that the Euphrates and other rivers froze, withered seeds and trees in $607 .{ }^{18}$

${ }^{11}$ Michael the Syrian, Chronique, III, 88, IV, 531.

12 Ibid., III, 127, IV, 554.

13 Ibid., III, 109, IV, 542.

14 Ibid., III. 239, IV, 617.

15 This is also true in the reverse direction. The Chronicle of Zuqnin omits disasters noted by Michael.

${ }^{16}$ Harrak, Chronicle of Zuqnin, 89, 100, 116-17, 123.

${ }^{17}$ Michael the Syrian, Chronique, II, 374, IV, 387.

18 Ibid., II, 378, IV 390. 
Since he does not locate the drought of 611, when crops perished and the lack of wheat and other cereals caused a famine, ${ }^{19}$ it may have been more general.

After this cluster of events Michael mentions nothing until 647, when a violent wind uprooted trees. ${ }^{20}$ This was followed in 669 by a severe winter with much cold, ice, and snow that withered olive trees and grapevines in all of Syria and Mesopotamia. ${ }^{21}$ There was another very severe winter before 684 with much snow and ice, when the Euphrates froze for six days, the ground froze, olives withered everywhere and grapevines in certain places, and people and domestic animals died of the cold. ${ }^{22}$ The great famine of 687 was presumably caused by a lack of grain, because wheat was sold at one modius for three dinars then. He does not say why wheat was scarce, but he does say that the price of three modii of wheat for one dinar caused by a drought in 694 was expensive. ${ }^{23}$ Another freeze in 706 withered olives and vines. ${ }^{24}$ In May of 713 there were locusts and a violent wind that uprooted trees, and a hard freeze in April of 714 withered plants, vines, and trees. ${ }^{25} \mathrm{~A}$ lack of rain and snow, presumably in the winter of 720-21, caused springs to dry up and rivers to go down by August and September resulting in a shortage of cereals and all kinds of vegetables and the desertion of

${ }^{19}$ Michael the Syrian, Chronique, II, 401, IV, 403.

${ }^{20}$ Ibid., II, 445, IV, 429.

${ }^{21}$ Ibid., II, 456, IV , 436. Sebeos mentions an extremely cold winter in Armenia in the 650's; see R.W. Thomson, The Armenian History attributed to Sebeos (Liverpool: Liverpool University Press, 1999) I, 146.

22 Michael the Syrian, Chronique, II, 470-71, IV, 444.

23 Ibid., II, 474, IV, 447.

${ }^{24}$ Ibid., II, 480, IV, 450. Michael also used the Chronicle of Jacob of Edessa (d. 708) up to 710, when it ends. Evidently the last two years were the work of a continuator. Michael says that he is beginning his own work in 711 (Ibid., II, 482-3, IV, 452), but he still used the work of Dionysius of Tell Mahre.

${ }^{25}$ Ibid., II, 482, IV, 452. The Chronicle of Disasters mentions drought in 713, along with the locusts, the violent gale in May that uprooted trees, and heavy hail in various regions that damaged vineyards and plants. See S.P. Brock, "A chronicle of disasters dated AD 716," in A. Palmer (ed.), The Seventh Century in the West-Syrian Chronicles (Liverpool: Liverpool University Press, 1993) 46. The latter also mentions heavy hail that destroyed plants and seedlings in 716 (Ibid., 47). 
many places. ${ }^{26}$ The heavy rain that caused a flood at Edessa in March of $739^{27}$ is probably the same event that the Chronicle of Zuqnin places in 742-3, when there was a severe winter with heavy snow followed by strong winds and rainstorms that caused floods on the Tigris at Amida and on the Daysan at Edessa. The latter wreaked havoc throughout the plain of Edessa and Harran, ${ }^{28}$ presumably causing damage to agriculture. According to Michael the winter of $744-5$ was both cold and dry. There was a hard freeze in January, when large rivers froze, and the lack of rain caused a great famine accompanied by an epidemic of bubonic plague. Farmers were reduced to seeking to work for bread, but no one hired them. ${ }^{29}$ The Chronicle of Zuqnin puts this in 743-4, when there was no winter rain and widespread severe famine. ${ }^{30}$

Michael records no more climatic disasters for the rest of the eighth century, but the Chronicle of Zuqnin mentions three successive hard winters in the entire southern region beginning in 750-51. Presumably this was in the southern Jazira if not southern Syria and Palestine, but, since rivers, including the Tigris, froze, this probably refers to the region south of the mountains. Heavy ice and hoarfrost settled on and damaged grapevines, olive trees, and gardens, while seeds perished under the snow or were up-rooted by the frost. After the snow melted the wheat was attacked by mildew and locusts, many fields went unharvested, and there was a famine. ${ }^{31}$ The same chronicle records widespread drought and famine in $772-3$, when there was no winter rain. This drought extended to the territory of Mawșil, where the entire crop dried

${ }^{26}$ Michael the Syrian, Chronique, II, 491, IV, 456.

${ }^{27}$ Ibid., II, 504-5, IV, 463.

28 Chabot, Chronique de Denys, 29-30 [32-33]; Harrak, Chronicle of Zuqnin, 165-6. The Chronicle of Zuqnin is notoriously cavalier about chronology.

${ }^{29}$ Michael the Syrian, Chronique, II, 506-7, IV, 464.

${ }^{30}$ Chabot, Chronique de Denys, 31-2 [34-5]; Harrak, Chronicle of Zuqnin, 167. This may have been related to the great drought in Iberia, that lasted from 748 to 753 , allowing for vagaries in chronology. See ${ }^{c}$ A.D. Taha, The Muslim Conquest and Settlement of North Africa and Spain (London/New York: Routledge, 1989) 227, 229. $184-6$

${ }^{31}$ Chabot, Chronique de Denys, 50-1 [56-8]; Harrak, Chronicle of Zuqnin, 
out, and also affected the east (the Jazira) and the south. ${ }^{32}$ In the fall of 773 there was an early winter, much snow fell in October and stayed on the ground, crushing vineyards and grapes. Hail as large as pebbles damaged trees and vineyards, and the harsh winter and wind destroyed vineyards and olive trees, dried up fig trees, and ravaged pomegranate, palm, and apple trees. ${ }^{33}$

The Chronicle of Zuqnin ends in 775, so it cannot be used as a check on Michael after that. Michael only mentions two climatic disasters that affected agriculture in the ninth century. One probably occurred in 810 , which began with a mild winter with moderate rain, when seeds and crops sprouted everywhere. But at the end of January the north wind blew for eight days and withered everything, mainly in the territory of Mawsil and the Jazira; there was absolutely nothing that year, neither grain, nor grapes, nor fruit. ${ }^{34}$ A rainless winter in 842 was accompanied by much snow and freezing weather. Seeds failed to germinate after March resulting in high wheat prices, famine, and disease. ${ }^{35}$

The Chronicle of Dionysius of Tell Mahre ends in 843, ${ }^{36}$ which probably explains the major gap in Michael's information between the mid-ninth and early twelfth century. He has abundant information for the twelfth century, during his own lifetime, about climatic disasters which he probably experienced himself. This begins with a severe winter in 1121-2, when the Euphrates and other rivers froze, ${ }^{37}$ and a general drought in 1123 followed by a great famine, especially in the east (the Jazira), that evidently lasted until $1125 .{ }^{38}$ There was another severe winter in $1127-8,{ }^{39}$ while a

32 Chabot, Chronique de Denys, 136, 145-6 [165,175-7]; Harrak, Chronicle of Zuqnin, 266, 274-6.

${ }^{33}$ Chabot, Chronique de Denys, 159, 161, 169 [192, 194-5, 203]; Harrak, Chronicle of Zuqnin, 287, 289, 296.

${ }^{34}$ Michael the Syrian, Chronique, III, 23, IV, 490. This may have been connected to drought and famine at Salakh in about 819. See E.A. Wallis Budge, The Book of the Governors, (London: K. Paul, Trench, Trübner \& co. ltd., 1893) I, 168, II, 337-8.

35 Michael the Syrian, Chronique, III, 108, IV, 541. This drought may have been related to one in al-Andalus in 846-7. See Barceló, "Plagues de llagost," 77.

${ }^{36}$ Michael the Syrian, Chronique, III, 111, IV, 543.

37 Ibid., III, 209, IV, 599.

${ }^{38}$ Ibid., III, 212, 222, IV, 601, 606.

${ }^{39}$ Ibid., III, 225, IV, 608. 
two-year drought beginning in 1133 caused famine in many places, especially on Cyprus. ${ }^{40}$ The winter was severe again in 1135-6 and began mildly in 1136-7 but turned severe in January, when the Euphrates and other rivers froze, and there was much snow. ${ }^{41}$ The winter of 1139-40 was severe from December to February, the Euphrates froze again, and there was no rain until May. When the rain came, there was a late harvest. ${ }^{42}$ Hail broke trees and grapevines in the region of Militene in May of 1141, while in June a violent wind uprooted the rest of the trees. ${ }^{43}$ In the general drought of 1148 the springs dried up, and many places without rivers and fountains were deserted. The drought lasted until midDecember 1149, when the rain came, the land was well watered, and there was a mild winter. ${ }^{44}$ The winter was severe again in 1151-2 with unprecedented amounts of snow as late as March. When the precipitation turned to rain, there was too much; abundant rain everywhere destroyed the seeds, crops, and everything that had been sown, especially along the rivers. ${ }^{45}$

The late twelfth century was even worse. There was a general dearth of wheat in 1165, especially in the region of Antioch and Cilicia. ${ }^{46}$ A series of bad years began in 1172, when a widespread, sudden cold snap, accompanied by rain and snow, occurred in September in the territory of Mawșil, the Jazira, Syria, Iran, Armenia, Palestine, and Egypt. Michael's specific reference to the destruction of grapevines, olive trees, cotton, and sesame on this occasion probably applies to Syria, the Jazira, and the territory of Mawșil. ${ }^{47}$ This was followed by a great famine that lasted four years (1173-6) throughout Cappadocia, Syria, Palestine, the territory of Mawsil, Armenia, and Iran as far as Sistan and the borders of India. ${ }^{48}$ In September and October of 1173 the crops were destroyed by snow again, and during the winter of 1173-4 rivers, fountains, and springs froze, so that people, animals, and birds

\footnotetext{
${ }^{40}$ Michael the Syrian, Chronique, III, 235, IV, 614.

${ }^{41}$ Ibid., III, 243; IV, 617-18.

${ }^{42}$ Ibid., III, 250-51, IV, 623-4.

${ }^{43}$ Ibid., III, 252-2, IV, 623-4.

${ }^{44}$ Ibid., III, 277, 282-3, IV, 638, 640-41.

45 Ibid., III, 299-300, IV, 650-51.

${ }^{46}$ Ibid., III, 325, IV, 679.

${ }^{47}$ Ibid., III, 348-9, IV, 701.

48 Ibid., III, 349, 357, IV, 703, 707.
} 
perished as much from thirst as from hunger. These conditions were repeated from March to mid-June 1175.49 There was also too much rain in 1174-75 causing a destructive flood of the Tigris at Baghdad. Although the fruits of trees and vines did not prosper that year, wheat seeds and other grains sprouted after the flood receded. ${ }^{50}$ After four years of famine herbs and crops began to grow again in the summer of $1176,{ }^{51}$ but drought in the spring of 1177 withered seeds and all the grains. Thirst caused many villages to be abandoned, especially around Jerusalem and throughout Palestine, in southern Syria, in the region of Nisibis, and in Tur 'Abdin. Crops went unharvested in the region of Mawșil. ${ }^{22}$ Then the drought ended, which had caused people and animals to perish, but the famine persisted everywhere, because the crops did not prosper that year, and the poor perished at Jerusalem, Damascus, Aleppo, and in the desert. ${ }^{53}$ This probably means that people and animals had water to drink, but that the rain came to late for the crops. There was another drought in 1178-79, and the crops withered causing wide-spread famine in Syria, Palestine, Arabia, the Jazira, the territory of Mawșil, and Armenia. There was absolutely no wheat or other grain to be found at Damascus and its vicinity, many people died of famine, and many left for distant lands. Then in mid-spring the rain came, crops prospered, and there was great abundance everywhere. ${ }^{54}$ There was so much rain at Antioch in May of 1179 that there was flooding, but the winter of 1179-80 was mild at Antioch. ${ }^{55}$

[12] Michael's information about the immediate effects of climatic disasters on agricultural production from the seventh to the midninth century, and again in the twelfth century, cannot be used to determine whether normal agricultural production was increasing or decreasing. But it is an excellent source for what kinds of crops were affected and for economic distress, price inflation, famine, mortality among humans and domestic animals, the abandonment of land, and emigration. It is worth noting that extreme cold, snow,

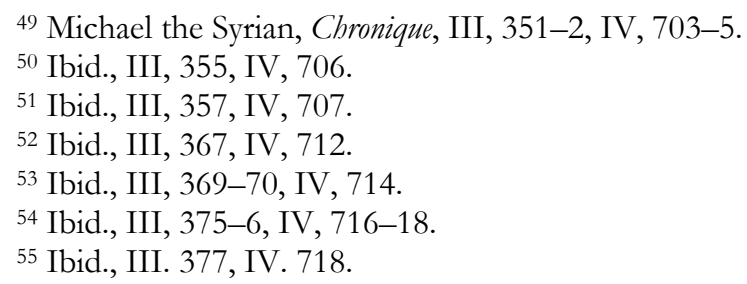


ice, hail, and violent winds could be as destructive to crops as drought was in the Jazira and northern Syria. If the olive trees that withered actually died, along with those that were uprooted, the fact that it took newly-planted olive trees five years to bear fruit means that the production of olive oil was reduced for that long after each event.

Arguably this should have reduced the tree-pollen count, and there is some evidence that this was so, provided by core samples from northern Palestine. Benjamin Kedar cites material from two bore-holes drilled by Aharon Horowitz in a swamp at the headwaters of the Jordan River, that shows a decrease in the percentage of arboreal pollen in the seventh century. Since the cores came from an uninhabited swamp, Kedar suggests that the decrease should be explained by some natural change rather than human (read: nomadic) activity. ${ }^{56}$ This is relevant because Kedar uses the Apocalypse of Pseudo-Methodius to argue that Arabs really might have cut down trees and destroyed the vegetation of the mountains at the time of the Muslim conquest, although he admits that vegetation could have been at least partly reduced by natural causes. ${ }^{57}$ However, the chart published by Kedar (figure 3) shows a decline in tree-pollen that was much longer than the seventh century, although it began then. One of the curves for the two bore-holes has a much sharper decline than the other, but both of them begin at the line on the chart between "Byzantine" and "Early Arabic" (however defined) and then continue to fall until about the year 1000, at the line between "Early Arabic" and "Crusades." 58 On the face of it this seems to indicate a long term trend unfavorable to trees.

Kedar also cites a core taken from the southern part of the Sea of Galilee by Uri Baruch, that shows a steady, dramatic decrease in the percentage of arboreal pollen from about 180 to about 880 . This was mostly due to a reduction in olive pollen, which Baruch explained by a decrease in oleiculture caused by humans. ${ }^{59}$ Kedar notes that subtracting the olive values from Baruch's total pollen

${ }^{56} \mathrm{~B}$. Kedar, "The Arab Conquests and Agriculture: a seventh-century apocalypse, satellite imagery and palynology," Asian and African Studies 19 (1985): 13.

${ }^{57}$ Ibid., 8-9, 13.

${ }^{58}$ Ibid., 14.

${ }^{59}$ Ibid., 13. 
values produces a curve that peaks at about 650 followed by a slight decline until the late ninth century. Baruch's curves also show a decline in evergreen oak and pistachio pollen, which usually grow where land is not plowed, similar to those from Hula. Kedar concludes that these declines may have been caused by a natural change as well as by nomads, ${ }^{60}$ and uses this information to advance the hypothesis that a deterioration in the climate in the seventh century (whatever caused the drop in pollen) might have contributed to nomadic migration into settled territory, and that both together might have reduced the vegetation. ${ }^{61}$

But the evidence presented by Horowitz and Baruch could be taken in another direction. It is difficult to avoid the conclusion that the information on climatic disasters presented by Michael and others goes a long way toward explaining why the arboreal pollen count fell from the seventh to the ninth or tenth century. Severe weather conditions do seem to have become more frequent from about the mid-seventh century. Granting that northern Palestine is on the southern edge of the same weather system that affects northern Syria and the Jazira, conditions might not have been exactly the same in any given year. A hard freeze in the north might not have been quite as cold in the Judean Hills, while a dry year in the north might have been even drier in the south. It is worth repeating that freezing weather and gale force winds were at least as important as drought in destroying trees, and are unlikely to have attracted nomads. But, if the arboreal pollen curves are to be trusted, then they reflect a long term trend, possibly largely explained by the long term effects of the recurring climatic events recorded by Michael and others. It is thus possible to suggest that the frequency of these events over a period of two centuries or more caused an absolute reduction in arboriculture. Simply put, from the seventh to the ninth century, the weather destroyed trees faster than they could be replaced.

[16] Animal pests, especially plagues of locusts, also destroyed crops and caused famines. There is still no satisfactory explanation for why the numbers of locusts increase, but it appears to be related to changes in temperature and moisture in their permanent breeding areas. There is no regular periodicity or cycle to the

${ }^{60}$ Kedar, "The Arab Conquests," 14-5.

${ }^{61}$ Ibid., 15. 
outbreak of plagues of locusts. Their transition from the solitary to the gregarious or swarming phase and back again lasts two or three years and is affected by a combination of factors. Hatching can be accelerated by a rise in temperature. Locust eggs can survive freezing temperatures and develop much more rapidly when they warm up after being exposed to low temperatures. Abnormally dry weather may also increase the chances of eggs surviving the winter and increase the number of locusts. Plagues tend to occur when spring rains follow several years of dry springs and increase the vegetation. Overgrazed pastures can also encourage breeding, because grass is replaced by the weeds favored by locusts. The swarming phase occurs when favorable breeding conditions results in the crowding of many locusts in a limited space. ${ }^{62}$ The hatching of locust eggs in the spring means that the swarms arrive just when crops are ripening.

Two species of locust cause plagues in western Asia. The Moroccan locust (Dociostaurus maroccanus, Thumb.) is found in the dry hills and mountains of the Mediterranean region and as far east as Central Asia. In western Asia it has permanent breeding areas in central Anatolia and the Transcaucasus and apparently in the dry, stony, semi-deserts on both sides of the middle Euphrates river. ${ }^{63}$ From these zones it invades the plains occasionally and can survive there for several generations but not permanently. However, when swarms appear in temporary breeding areas, they increase extremely rapidly. ${ }^{64}$ After its eggs are deposited in early summer there is an interruption in development (an embryonic diapause), possibly because of insufficient moisture. Development resumes the following spring, but the larvae can be mature without hatching. Some external stimulus is necessary, such as a rise in temperature, soil humidity, or light. Sudden mass hatchings have been observed after rain. The eggs usually hatch between March and April and the hopping locusts go through five stages before they acquire wings by mid-May to July, become sexually mature,

62 Barceló, "Plagues de llagost," 71, 74; B.P. Uvarov, Locusts and Grasshoppers (London: The Imperial bureau of entomology, 1928) 34-8, 145-7, 160, 231, 233.

${ }^{63}$ Uvarov, Locusts and Grasshoppers, 224-9.

${ }^{64}$ Ibid., 229-31. 
mate, deposit their eggs, and die. ${ }^{65}$ The Moroccan locust will eat anything. Grain crops, which are still green when the bands of hoppers are formed, suffer the most, but it does enormous damage to cotton. It will also nibble plants for water, not for food, eating the stems of leaves on trees and thus defoliating them. ${ }^{66}$

The Desert locust (Schistocerca gregaria, Forsk.) is found across Africa, in Palestine and Arabia, and in Iran, Baluchistan, and the Punjab. It has no diapausal stage; the eggs hatch in sixteen to forty days, and the larval period of hoppers lasts from forty to fifty days. Since the swarms appear in early spring, when the crops are green, the next generation of hoppers eats the same crops and those that ripen later. It can destroy an entire year's harvest, devouring vegetables, garden crops, and vines, and damaging orchards and vineyards. Its invasions of the regions of Palestine and the Transjordan have been infrequent, but it can do enormous damage to olives, vines, and other crops. ${ }^{67}$

Michael does not mention the invasion of locusts in May of 499 and the subsequent plague of locusts in March of 500, when the hoppers devoured everything from the territory of Mawsil (Assur) to the Mediterranean and the land of Urtea (Armenia) in the north, that caused famine and high prices. ${ }^{68} \mathrm{He}$ does say that many locusts caused much damage in 582-3, which probably explains the lack of bread that year. ${ }^{69}$ The drought of $600-1$ was followed by unprecedented numbers of locusts in Syria in the spring of 602, that destroyed the seeds and the fruit of trees. Three years later (spring 605) the eggs they laid hatched and locusts caused ruin and increased the famine. ${ }^{70}$ In 678-9 rats multiplied in Syria and Phoenicia, destroyed the seeds, and caused a great famine, and in the following year (spring of 680) there were

${ }^{65}$ Barceló, "Plagues de llagost," 72; Uvarov, Locusts and Grasshoppers, 36-7, 39, 44-50, 146, 229.

66 Uvarov, Locusts and Grasshoppers, 74, 229-30.

${ }^{67}$ Ibid., 252-8, 261.

${ }^{68}$ Harrak, Chronicle of Zuqnin, 38-9; P. Martin, Chronique de Josue le Stylite (Abhandlungen für die Kunde des Morgenlandes, VI. Band, No. 1; Leipzig: Deutschen Morgenländischen Gesellschaft, 1876) 30 [25], 34-5 [30].

${ }^{69}$ Michael the Syrian, Chronique, II. 352, IV, 375. This coincides with the beginning of Dionysius of Tell Mahre's Secular History.

${ }^{70}$ Ibid., II, 374, IV, 387. 
locusts. ${ }^{71}$ To his brief note that innumerable locusts arrived in May of 714 the Chronicle of Disasters adds that there was a lack of rain that year and that the locusts destroyed vineyards, sown fields, and plants. ${ }^{72}$ Michael has more to say about a plague in the spring of 721, when locusts were very numerous at harvest time, ate the grapevines, and ate fig and olive trees to the point that their trunks withered. Then they destroyed all their fruit, and there was a shortage of wine everywhere. ${ }^{73}$ There was probably also a shortage of olive oil. This was followed by a drought in 721-2; then many locusts destroyed the harvest again in April of 723 , increasing the suffering of people and animals from the lack of all kinds of food. ${ }^{74}$ Michael omits the infestation of locusts and other insects that followed the harsh winter of $750-51$, when the damage to vineyards, trees, and fruit by the hoppers and to wheat and barley by weevils at harvest time increased the famine, that is described in the Chronicle of Zuqnin. ${ }^{75}$ However, he mentions invasions of locusts in the spring of 763 and 766 , that devoured the seeds and caused damage, which the Chronicle of Zuqnin omits. ${ }^{76}$

Overgrazing in the Jazira may have contributed to the breeding of locusts in the eighth century. According to the Chronicle of Zuqnin the Jazira was full of cattle, herds of horses, and flocks of goats in the $760 \mathrm{~s}^{77}$ On top of that the drought of $772-3$ led the Banu Taghlib and $\mathrm{Ma}^{\mathrm{e}} \mathrm{d}$ to move north with their sheep and camels for pasture along the foothills. They consumed the open pasture leaving none for cattle. That livestock exceeded the resources is indicated by the information that, in the severe winter of 773-4, there was no pasture for grazing animals and no grain for stall-fed

${ }^{71}$ Michael the Syrian, Chronique, II, 457, IV, 436.

${ }^{72}$ Brock, "Chronicle of Disasters," 46; Michael the Syrian, Chronique, II, 482, IV, 452.

${ }^{73}$ Michael the Syrian, Chronique, II, 490, IV, 455-6.

${ }^{74}$ Ibid., II, 491, IV, 456.

75 Chabot, Chronique de Denys, 52-3 [59-60]; Harrak, Chronicle of Zuqnin, 186-7.

${ }^{76}$ Michael the Syrian, Chronique, II, 524, IV , 474-5.

77 Chabot, Chronique de Denys, 83 [98], 98 [116]; Harrak, Chronicle of Zuqnin, 216, 230. 
livestock, with the result that goats, sheep, oxen, horses, and donkeys perished in the northern Jazira. ${ }^{78}$

Then, in the spring of 785 , winged locusts arrived, and the entire Jazira was full of them. After they devoured the wheat, barley, and all the vegetables, they laid their eggs everywhere in the plains and in the mountains. After remaining in the ground for one month, their progeny emerged and began to crawl over the ground devouring everything they found, spreading especially at Edessa, Saruj, and Resh Kepha. When they had consumed everything in the Jazira, they passed to the west (Syria), where they destroyed all the grain and then devoured the grapevines, trees, and all kinds of crops. This was followed by famine for the next three years caused by the high price of bread, wine, oil, and all sorts of vegetables. ${ }^{79}$ Judging by the short incubation period, these were evidently Desert locusts. ${ }^{80}$

Plagues of locusts continued in the ninth century. In the spring of 804 locusts destroyed every kind of crop everywhere. ${ }^{81}$ Between that and 808-9 there were locusts for three years that laid their eggs and reproduced (i.e. the Jazira became a temporary breeding area), ravaged the entire Jazira, and caused famine. ${ }^{82}$ After violent hail had destroyed the field crops in 829-30 or 830-1, locusts devoured the grapevines and olive trees, laid their eggs, and the next year devoured everything: field crops, vines, and trees. ${ }^{83}$ The winter of 842-3 was cold and dry. Seeds did not germinate until April, when it rained, but hail ravaged most of the fields in the Jazira and the west (Syria). Then locusts devoured the late seeds, the cotton, and other crops. ${ }^{84}$

Since this is where the Chronicle of Dionysius of Tell Mahre ends, there is the usual gap in Michael's information about natural disasters between the mid-ninth and eleventh centuries. But there is also a change in what he recounts. For whatever reason locust

${ }^{78}$ Chabot, Chronique de Denys, 146 [176-7], 160 [193]; Harrak, Chronicle of Zuqnin, 275-6, 288.

${ }^{79}$ Michael the Syrian, Chronique, III, 4-5, IV, 479-80.

80 That they were different is recognized by Michael, who says they were called "canine" (kalbaita) locusts.

${ }^{81}$ Michael the Syrian, Chronique, III, 17, IV, 487.

82 Ibid., III, 19, IV 488.

83 Ibid., III, 78-9, IV, 524.

${ }^{84}$ Ibid., III, 109, IV, 542. 
infestations in the late eleventh and early twelfth centuries caused little damage; Michael ascribes this to divine intervention. One such event occurred in 1080-185 and another in 1120-1. On the latter occasion flying locusts came to Militene and ate a little of the crops, perished, and disappeared, having laid their eggs (locusts normally die after they mate and deposit their eggs). A little while later thin locusts appeared, that nibbled the trees and vines a bit and perished at once. ${ }^{86}$ These were evidently Desert locusts again. In the spring of 1135 numerous locusts in the region of Edessa either left without causing damage, or retired to uncultivated land and ate hay, or invaded fields of cotton, vegetables, or sesame and devoured the refuse without harming the crops. ${ }^{87}$ Locusts arrived again in May of 1136, after a severe winter, but caused no damage. ${ }^{88}$ The locusts were back to normal again in 1195-6, when they devoured grain and grapevines all year from the borders of Egypt to Iberia (Georgia) and from Iran to the Black Sea. ${ }^{89}$ Michael's Chronicle ends in this year.

Presumably all of the factors that served to reduce agricultural production in any particular year thereby reduced the ability of the rural population to pay taxes, which tended to be met by more oppressive measures from the government for their collection. Michael does not have much to say about this, but he does tell how, when 'Abdullah ibn Tahir besieged Arab rebels led by Nașr ibn Shabat at Kaishum in 823, he required the people of Saruj to collect the wheat and straw his army needed. The entire Jazira and the west (Syria) were so hard pressed that people reaped wheat, barley, and other grains prematurely, threshed, and delivered them. Meanwhile Nass r went around massacring the reapers and burning everything he found..$^{90}$ Michael also says that, in the early ninth century, farmers were prevented from harvesting grapes before the government collected one dinar for every 1,000 vine-stocks. Nor could they press them before paying. Wine was kept in the barrels until the sellers and buyers had been taxed. Taxes were collected on the roads and at the gates of cities, at the beginning of the harvest,

\footnotetext{
85 Michael the Syrian, Chronique, III, 177, IV, 582.

${ }^{86}$ Ibid., III, 208-9, IV, 598-9.

${ }^{87}$ Ibid., III, 238-9, IV, 615-17.

${ }^{88}$ Ibid., III, 243, IV, 618.

${ }^{89}$ Ibid., III, 413, IV, 738.

${ }^{90}$ Ibid., III, 52, IV, 510.
} 
on hay-stacks, when the farmers cleared out caterpillars, and when they picked olives. ${ }^{91}$

Outright pillaging also occurred at the hands of brigands, rebels, and armies. In 812 a murderer named ${ }^{\circ} \mathrm{Amr}$ escaped from prison at Callinicus and fled to Samosata, where he killed the amir and pillaged the merchants. Then he went with his followers to Palestine, where they engaged in brigandage, killed, and pillaged. 'Amr then joined forces with the rebel, Nașr ibn Shabat, and the two of them crossed over to the Jazira and massacred, pillaged, collected wealth, and burned villages around Harran and Edessa. ${ }^{92}$ In 842 the rebel, Tamim Abu Harb, followed by 30,000 starved and naked people, pillaged and killed in Palestine. ${ }^{93}$

[26] The same plagues, climatic disasters, and human depredation that reduced agricultural production also affected domestic and wild beasts that perished from drought, cold, and the lack of fodder. The economic consequences included a reduction in the supply of wool, meat, and milk products, the loss of draught animals for plowing, grinding grain, and pressing grapes and olives, that exacerbated any agrarian crisis, and the loss of pack-animals for transport. The plague of 543-44 struck domestic cattle and wild animals, and John of Ephesus, who travelled in Cilicia, Moesia, Syria, Iconium, Bithynia, Asia, Galatia, and Cappadocia during the plague years, noted herds of sheep, goats, oxen, and pigs that went feral, because there was no one to tend them. ${ }^{94}$ Michael merely reports that during this plague fields went uncultivated for lack of cattle to plow them. ${ }^{95}$ Beyond this he has little more to say. He does not note the heavy hail that killed camels and donkeys in April of $715,{ }^{96}$ the plague among horses in $763-4,{ }^{97}$ or the heavy snow that killed cattle and sheep in 768-9.98 He does mention a plague among chickens at Militene in 1141, ${ }^{99}$ and how cattle, donkeys, and

${ }^{91}$ Michael the Syrian, Chronique, III, 107, IV, 540.

92 Ibid., III, 21-2, IV, 491-2.

${ }^{93}$ Ibid., III, 103, IV , 541-2.

${ }^{94}$ Harrak, Chronicle of Zuqnin, 100, 105.

${ }^{95}$ Michael the Syrian, Chronique, II, 245, IV, 309.

${ }^{96}$ Brock, "Chronicle of Disasters," 47.

${ }^{97}$ Chabot, Chronique de Denys, [77]; Harrak, Chronicle of Zuqnin, 200-1.

${ }^{98}$ Chabot, Chronique de Denys, 95 [112-3]; Harrak, Chronicle of Zuqnin, 227.

${ }^{99}$ Michael the Syrian, Chronique, III, 251, IV, 623. 
horses died of the cold in their stables during the winter of 1175 , while the carcasses of sheep and goats piled up under the snow. ${ }^{100}$ He also reports 'Abd al-Malik's order to kill all the pigs in about 694,101 and how the Muslims killed all the pigs in the streets of Takrit in 820,102 but those were not natural disasters.

Just as the tale of agrarian disasters can be used to identify what the main crops were, the effects of natural disasters on animals can be used to identify the livestock in the economy. It is clear that bovine cattle, horses, donkeys, goats, sheep, camels, and pigs were all raised by the sedentary population. Nomadic pastoralists also raised cattle, sheep, goats, horses, and camels, so any conflict over the use of land was not between farmers and herdsmen but between sedentary and nomadic populations over pasture for the same animals. Michael has little to offer about nomadic pastoralism before the eighth century beyond the usual association of Arabs with camels and sheep. ${ }^{103}$ But he has a valuable reference to the Christian Arabs of the Banu Tanukh who lived in tents in the vicinity of Aleppo in 779, rode Arab horses and were richly dressed. ${ }^{104} \mathrm{He}$ describes how their encampment near Aleppo had grown into a sprawling town by 813 , which was so large it had no wall, but was very rich because of its resources and merchants. In that year the Tanukh were defeated by the Banu Qais and left for Qinnasrin, abandoning their houses and great encampments full of wealth, which were pillaged by the Banu Qais and the people of Aleppo. ${ }^{105}$

Camels were also raised by villagers. Michael tells of a scam operated by a governor named 'Ali at Damascus in 840, who bought weak, thin camels and sent them to the villagers to nourish them during the winter. When the camels perished from weakness, he told them the camels belonged to the ruler and charged them thirty dinars per camel. There were also camels in the villages around Cyrrhus in 840, where a camel-driver allowed his camels to urinate on the road. ${ }^{106}$

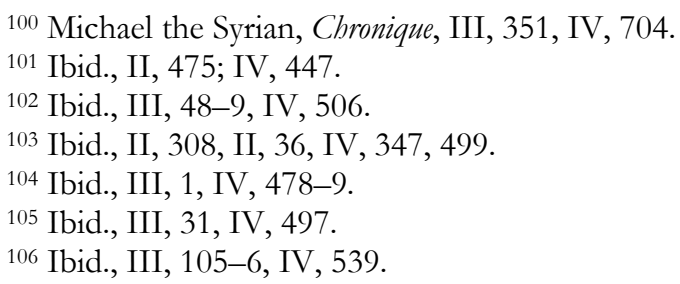


[29] In the twelfth century Michael mentions that snow covered the encampments of the tent-dwelling Arabs in 1173, ${ }^{107}$ but his best information is about the transhumance of Türkmen. He describes how the tent-dwelling Türkmen would come down to spend the winter in the desert south of Syria, where snow did not fall, there was no ice, and pasture could be found. In spring they would return to the northern region for pasture. During both migrations the routes were full of their livestock, and the Kurds would steal their sheep, horses, cattle, and camels, and even kill their men. This led to a battle between the Türkmen and the Kurds in 1185, when the Türkmen drove the Kurds out of Syria and the Jazira. ${ }^{108}$

Except for famines during sieges, famine was caused by crop failure and the death of domestic animals. Sometimes Michael records famines without saying what their immediate cause was, but these can be used as indirect evidence for a reduction in agricultural production. Human mortality during famines also reduced the labor force so that sometimes crops went unharvested. The hoarding of grain by the rich during famines meant that the poor (i.e. the work force) suffered the most. Accounts of famines often have information about the expedients to which people were reduced in order to find food. People also died from gorging when the famine was over.

According to John of Ephesus there was famine for eight years from 546-7 to 554-5 in the region of Amida. ${ }^{109}$ Michael notes that people died from gorging after the famine and plague during the reign of Justinian. ${ }^{110} \mathrm{He}$ also records a famine in the region of Marash in about 655 and how people went out to gather herbs. ${ }^{111}$ During the famine of 694 people made bread from lentils, peas, and oats, ${ }^{112}$ while they collected animal manure and ground the kernels and skins of grapes to make bread in the famine of $745 .{ }^{113}$ When women and children went out to gather herbs during the famine caused by locusts in the Jazira in 808 , they were devoured

\footnotetext{
107 Michael the Syrian, Chronique, III, 352, IV, 704.

108 Ibid., III, 400-1, IV, 732-3.

109 Harrak, Chronicle of Zuqnin, 116, 119.

110 Michael the Syrian, Chronique, II, 244-5, IV, 309.

111 Ibid., II, 447, 449, IV, 431, 433.

112 Ibid., II, 474-5, IV, 447.

113 Ibid., II, 508, IV, 466.
} 
by wild beasts. ${ }^{114}$ Michael does not say what caused the great famine in Khurasan in 833, but he reports that people ground the husks of straw to make flour and cooked it; they cut up palms, dried them, ground them in a mortar, and made bread; and they collected date stones, crushed and ate them. ${ }^{115} \mathrm{He}$ also notes that there was a famine in Egypt following the last, great Coptic revolt in the reign of al-Ma'mun. ${ }^{116}$ During the famine in the Jazira in 842, the poor, who went out to collect firewood or herbs for nourishment instead of bread, perished from the cold, while the rich, seeing that they had no more bread or seed in the ground, stopped taking pity, selling wheat, and relieving the poor. Salt, wheat, and walnuts grew expensive in a land that normally exported walnuts and wheat. ${ }^{117}$

Although Michael has almost nothing to say about the climatic causes of disasters in the eleventh century, he records a widespread, great famine in 1037, when mortality among humans and domestic and wild animals was so great that people said it was the end of the world. ${ }^{118}$ The famine of 1082, when bread and wine were expensive, ${ }^{119}$ was evidently caused by a failure of the grain and grape crops. In the thirteenth century he tells how the Templars distributed wheat to the poor from their store rooms full of wheat, barley, wine, and vegetables during a famine at Jerusalem in $1120 .{ }^{120}$ In contrast at the beginning of the great famine in the winter of 1173-4, because Ismail, the ruler of Sebastea in Cappadocia, refused to distribute his hoarded wheat, the starving people attacked and killed him together with his wife and 500 members of their household, seized all they could, and fed themselves. ${ }^{121}$ However, in the famine of 1178 Amaury, the "patriarch" of the Franks, distributed wheat and other grain abundantly at Antioch, but the Turkish amirs refused to allow a huge number of people, who had set out from Arabia driven by hunger, to cross the Euphrates lest they should make the famine

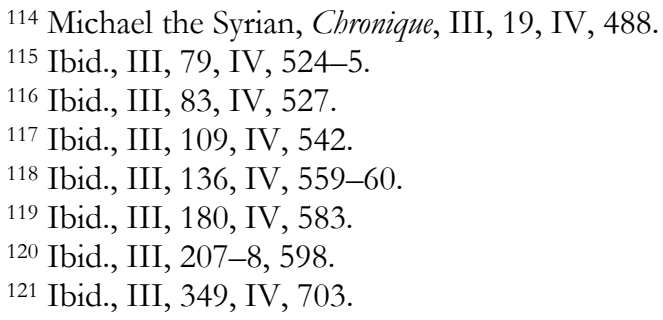


worse. When they crossed anyway, the Turks massacred about 100,000 of them; the survivors tried to recross the Euphrates but were drowned with their camels in the river. ${ }^{122}$

The human mortality from famine, the bubonic plague and other epidemics, and warfare substantially reduced the labor force, especially since the poor were the first to perish. Large numbers of people were also removed from Syria and the Jazira by the Persians in the warfare between the Sasanians and the Byzantines during the sixth and early seventh century and deported to their own territory. Captives were often enslaved as well. Deportation surely reduced economic production in the regions where captives were taken and increased it where they were resettled. One is tempted to speak of a labor crisis in Syria at the end of Late Antiquity. It would seem that the labor force in Syria was replenished by the Muslim Arabs with captives taken in Anatolia and among the Turks from the seventh to the end of the eighth century. Whether this was merely stabilizing or related to economic development remains to be seen.

Among many similar accounts in various sources Michael reports (probably from John of Ephesus) that in 575 Khusraw I took 90,000 captives at Dara and others from the regions of Qinnasrin and Antioch. A total of 292,000 captives were all sent to Persia. ${ }^{123}$ The 3,000 Persian slaves sent to Maurice by his general, Germanus, in 583124 hardly balanced the score. Apparently this began with the Arabs. When Mucawiya took Euchaita in 640, he carried off all its people into slavery: men, women, boys, and girls, ${ }^{125}$ and Maslama took captives at Tyana in $708 .{ }^{126}$ It is difficult to understand why al-Walid I would have ordered captive Christians to be killed in all the cities of Syria in $711 . .^{127}$ If there was already a surplus of captive labor, that would not explain the massive importation of captives over the next two decades. In 712 'Abbas ibn al-Walid returned from Antioch in Pisidia with many

${ }_{122}$ Michael the Syrian, Chronique, III, 375-6, IV, 717-8.

${ }^{123}$ Ibid., II, 311-2, IV, 349. Khusraw I had already deported farmers from Callinicus in 542. See Procopius, History of the Wars, II.xxi.32 (tr. H.B. Dewing, London: William Heinemann / New York: The Macmillan Co., 1914) 450-1.

${ }_{124}$ Michael the Syrian Chronique, II, 359, IV, 379.

125 Ibid., II, 431, IV, 423.

126 Ibid., II, 478, IV, 451.

127 Ibid., II, 479, IV, 452. 
captives. ${ }^{128}$ In 715 Maslama brought back many captives from Galatia, Pergamum, Sardis, and other cities, and from the land of the Turks. ${ }^{129}$ In 726 the Arabs took numerous captives from a large city in the land of the Turks, ${ }^{130}$ and in 727 Michael refers to prisoners and captives that the Arab troops brought and settled in Syria. ${ }^{131}$

It should be noted that the deportation and resettlement of captives continued under the 'Abbasi dynasty. In 769 the Arabs resettled captives from the valley of Marash and the land of Samosata in the land of Ramla, ${ }^{132}$ presumably as a rural population. Approximately 7,000 people were taken captive by the Arabs in the region of Ephesus in 781. The Byzantine emperor, Leo, retaliated by sending an army that took orthodox Syrian Christians captive and resettled them in Thrace. ${ }^{133}$ Michael also reports that, when alMahdi ordered Christian slaves to be sold at the beginning of his reign, the slaves fled. ${ }^{134}$ Many captives were taken again in 792 and 793 in Byzantine territory (Anatolia), particularly in Cappadocia, at the beginning of the reign of ar-Rashid. ${ }^{135}$ Michael has no more references to Arab military campaigns acquiring captives in Byzantine Anatolia after this, and, since this part of his Chronicle depends on Dionysius of Tell Mahre, that probably means that there were none. By the early ninth century the $\mathrm{A}$ Abbasis were preoccupied with their own internal problems, and captive labor was no longer imported from Anatolia. However, Michael does

128 Michael the Syrian, Chronique, II, 479, IV, 452.

${ }^{129}$ Ibid., II, 479, 483, IV, 452. These Turks were probably Khazars from north of the Caucasus.

130 Ibid., II, 490, IV, 457.

131 Ibid., II, 492, IV, 458.

132 Ibid., II, 526, IV, 476. Ramla had been founded by Sulayman (715-7). See T. Khalidi, "Tribal Settlement and Patterns of Land Tenure in Early Medieval Palestine," in T. Khalidi (ed.), Land Tenure and Social Transformation in the Middle East (Beirut: American University of Beirut, 1984) 183.

133 Michael the Syrian, Chronique, III, 2, IV, 497. This would have been Leo IV (775-80). Michael's chronology is at least one year off at this point. Theophanes puts this event in 770 . The people would not have been Chalcedonians, but Syrian Orthodox Christians from Michael's point of view.

134 Ibid., III, 3, IV, 478.

135 Ibid., III, 8, IV, 483. 
have information on the enslavement of Copts at the end of their revolt in Egypt in the reign of al-Ma'mun. Some 500 captive Copts were given as slaves to the Arabs and sent to Damascus, where they were sold. But Christians bought them back and freed them. ${ }^{136}$

Michael also has some information on enslavement in the twelfth century. He reports that in 1176 Türkmen invaded the northern part of Byzantine territory (probably Bithynia), seized approximately 100,000 people, killed all the men, and sold the women and children to merchants, who took them to Persia. ${ }^{137} \mathrm{He}$ also tells how, after driving off the Kurds in 1185, the Türkmen carried off 26,000 Armenians and sold them as slaves. ${ }^{138}$ Finally, he relates that 20,000 men and women, who were unable to ransom themselves for ten dinars apiece, were reduced to slavery, when Jerusalem fell to Salah ad-Din (in 1187). Four thousand old men and women were freed; 6,000 were divided among the troops of Salah ad-Din as slaves; he sent 5,000 to Egypt to make bricks to build the walls; and he left 5,000 at Jerusalem to rebuild the walls there. ${ }^{139}$

Otherwise, Michael does not have a great deal to say about exactly where enslaved captives were resettled or how they were employed. But he does indicate that some people had huge numbers of slaves; slaves were a form of property as well as labor. It is worth noting his report that the Christian plutocrat, Athanasius bar Gumaye of Edessa, owned 4,000 slaves in the early eighth century. ${ }^{140}$ Although it is important to know that Christians could own slaves, Michael also says that the Christians of Edessa were required to free their slaves in 825 , so the latter could become Muslims. ${ }^{141}$ 'Ubayd ibn Sari, who rebelled at Fusțat and in middle Egypt in 826, owned 80,000 slaves, most of whom were "Moors." ${ }^{142}$ When the caliph, al-Mu'tașim died in 843, some 8,000

136 Michael the Syrian, Chronique, III, 83, IV, 527.

137 Ibid., III, 309, IV, 715.

138 Ibid., III, 401-2, IV, 733.

139 Ibid., III, 405, IV, 734-5.

140 Ibid., II, 475, IV, 448.

141 Ibid., III, 62, IV, 514.

142 Ibid., III, 59, IV, 513. Chabot says this means that they were black, but they could have been Berbers. For Maureye as an ethnonym for the people of Mauritania see Harrak, Chronicle of Zuqnin, 231. 
slaves, who had been bought with silver, were freed. He also left 40,000 saddle horses and 20,000 baggage mules that were tended by 30,000 slave grooms. ${ }^{143}$

The free agricultural labor force in the Jazira appears to have been fairly mobile. The Chronicle of Zuqnin has much more information about this for the third quarter of the eighth century than Michael does in his entire Chronicle. It is clear that there was a landless labor force in the Jazira that worked for wages or merely for food in hard times. Landholding farmers might also work on someone else's land for extra income. The greatest demand for such labor was at harvest time. Sometimes a flood of refugees from drought, famine, or oppression elsewhere meant there was no work for the natives. Sometimes the mortality and flight from famine or plague left no one to harvest the crops. What Michael has to say fits this pattern. He describes a group of probably seasonal workmen in the village of ${ }^{~}$ Ufrai in the region of Mareash at the time of vintage in 655 , who were willing to exchange their wine for a meal. ${ }^{144}$ As already noted, he says that during the great famine and bubonic plague of 745 farmers would have worked for bread, but no one hired them. ${ }^{145} \mathrm{He}$ describes how the plague that broke out in 842 and lasted two years began in the Jazira and spread to Syria, Palestine and the coast, leaving many villages deserted and their fields without harvesters. ${ }^{146} \mathrm{He}$ also tells how an Arab of the Banu Iyad prevented a Christian from plowing his field and made him work on his own field in the early ninth century. This Arab also requisitioned a man and his family to reap his own crop and work with him. ${ }^{147}$

The labor requisitioned for sieges and building projects was supposed to be paid. ${ }^{148}$ They were at least given provisions in 715, when Maslama marched against Constantinople. According to Michael Maslama collected 12,000 workmen, 6,000 camels to carry

143 Michael the Syrian, Chronique, III, 104, IV, 543. The Christian patrician of Greater Armenia is said to have had over 100,000 slaves in 772-3. He was killed that year and his property confiscated by al-Manșur. See Chabot, Chronique de Denys, 148 [180]; Harrak, Chronicle of Zuqnin, 278.

144 Michael the Syrian, Chronique, II, 447, IV, 431.

145 Ibid., II, 605-7, IV, 464.

146 Ibid., III, 109-10, IV, 543.

147 Ibid., III, 107, IV, 540.

148 Chabot, Chronique de Denys, 82 [97]; Harrak, Chronicle of Zuqnin, 215. 
the weapons and siege equipment, and 6,000 donkeys to carry food for the camels and provisions for the workmen. ${ }^{149}$ The caliph arRashid also gathered many workmen to build Heraclea in 804 . The information that the people suffered famine because of the building of the city probably means that local farmers were requisitioned. Michael says that the caliph then ordered for the workmen to be paid full wages. ${ }^{150}$ In 814 the rebel, ${ }^{\circ} \mathrm{Amr}$, rebuilt the wall of Samosata with an army of poor Christians. ${ }^{151}$

Michael also has an important, first-hand account from Dionysius of Tell Mahre about the working conditions of the Coptic flax weavers at Tinnis in 826, when Dionysius was in Egypt himself. Dionysius relates how he addressed 'Abdullah ibn TTāhir, who was in Egypt suppressing the Coptic revolt, telling him that he had never seen such misery. When he had asked the people of Tinnis about it, they had told him that their town was surrounded by water, they had neither crops nor other resources, could not have herds, and the water they drank came from a distance and cost them four quze (dirbams) per pitcher. Their only work was flax, which their women spun and the men wove. The clothing merchants paid them one-half zuza (dirham) per day for it, which was not enough to feed them. But they had to pay five dinars when they were taxed. They were beaten and thrown into prison and (to borrow the money to pay the tax) were forced to mortgage their sons and daughters to work like slaves (for the creditors) for two years for one dinar. If a girl or a woman should have a child with the creditors, the weavers had to swear that they would not bother them about it. It also happened that it would be time to pay the tax again before a woman was liberated. They had asked Dionysius to tell the amir about their plight, so he would take pity on them. According to Dionysius the amir ordered for them to be taxed according to the system in the Jazira. The most well off should pay 48 zuze (dirhams), those of moderate means 24, and the poor 12 when the poll-tax was collected from them. ${ }^{152}$ In addition, Michael reports from Dionysius that before 835 some of the Copts taken to

\footnotetext{
149 Michael the Syrian, Chronicle, II, 484, IV, 453.

150 Ibid., III, 16, IV, 489.

151 Ibid., III, 27, IV, 494.

152 Ibid., III, 63-4, IV, 516.
} 
Iraq after the revolt were kept by al-Mu'tasim to weave clothing of linen according to the embroidery work of the Egyptians. ${ }^{153}$

There is a great contrast between the condition of the weavers of Tinnis and what Michael has to say about the rich. Evidently there was a class of wealthy, propertied, Christian notables in the Jazira. Michael's account of the career of one of them, Athanasius bar Gumaye of Edessa, is revealing in many ways. ${ }^{154}$ In the first place he was not only intelligent but noble, which is probably why he got an education, studying the books of the Church and secular literature (Michael does not say in which language/s). Secondly, his intelligence and learning got him a position in the Arab administration, where he made a fortune. 'Abd al-Malik entrusted his young brother ('Abd) al- ${ }^{-} A z i z$ to Athanasius when 'Abd al-'Aziz was appointed governor of Egypt. Athanasius became his tutor, and in addition to presents and wealth given to him by the caliph, the sons of Athanasius took one dinar from each of the soldiers, when they were issued their pay. Since there were 3,000 soldiers in Egypt, and one dinar apiece returned to Athanasius (at least annually), during the 21 years he was in Egypt he became very rich. Athanasius seems to have returned to Edessa afterwards, where he owned 4,000 slaves as well as villages, houses, gardens, gold, silver, and precious gems. Michael says that he owned three shops in Edessa, but this is probably mistaken. According to Bar Hebraeus, Athanasius owned 400 shops in Edessa, which seems to be more realistic, since he used the revenues (most likely rents) from his shops to build the church of the Mother of God in Edessa. He also built a baptistery in Edessa (the great church was held by Chalcedonians), which he decorated with gold, silver, and a revetment of marble. In addition he built churches and monasteries in many places in Egypt including two great and magnificent churches in Fustat. ${ }^{155}$ Before the time of ${ }^{\mathbf{e}}$ Abd al-Malik the Muslim soldiers in Egypt were given rations but not cash stipends, so Michael provides important information about military finance there. Athanasius is also a good example of the involvement of

153 Ibid., III, 84, IV, 529.

154 Michael does not give exact dates for the career of Athanasius, but his administrative service coincided with the reign of 'Abd al-Malik. Michael's account immediately follows his information that 'Abd al-Malik ordered all the pigs to be killed in about 694 in his text.

155 Michael the Syrian, Chronique, II, 475-6, IV, 447-8. 
members of the non-Muslim class of notables in administration, of the tremendous wealth held by some of them, and of the use of this wealth for patronage toward the Church.

The notables of Edessa intermarried so that property passed from one family to another through inheritance. Sometime during the seventh and eighth centuries the house of Iwannis Rasafaya at Edessa passed by inheritance to the Tell-Mahraye family and then to the Gumaye, when a woman of the Tell-Mahraye married a Gumaya. The house devolved to their son, Silvestros. ${ }^{156}$ Apart from what this tells us about inheritance by and from women, Iwannis Rasafaya had been very wealthy with a palatial house. When Khusraw II had stayed in Edessa during his exile, Iwannis had entertained him and displayed his wealth to show that he was richer than his rival, Marinus. He brought out gold and silver plates, tables, platters, spoons, and vases. The bowls and vases to drink wine, amphorae, phials, and carafes were all of silver. ${ }^{157}$ The wife of Iwannis had buried this treasure in the house, when Khusraw II exiled her to Persia after the fall of Edessa (in about 524-5). The sons of Silvestros inherited the house with the rest of his fortune, but they were debauched and dissipated their fortune. In about 803 they thought of digging in the house, because they had heard that a treasure was hidden there. When they found it, instead of using it wisely, they displayed even more luxury with horses and dogs for the chase. But, by selling the silver, their secret was out. Ar-Rashid imprisoned them at Callinicus and sent his eunuch to Edessa to confiscate everything, including vases of gold and silver, and Roman denarii. When their sister, who had been imprisoned in the house of a Chalcedonian, leapt to her death from a fourth-storey window, the caliph was grieved and freed the brothers, returning to them one-fifth of what the eunuch had taken. ${ }^{158}$ In this account Michael provides rare information about a coin hoard of Roman dinars that was buried when Edessa fell to Khusraw II, which would support the assumption that coins might have been buried when cities fell. That it was dug up nearly 200 years later is evidence for how long a hoard might stay in the ground. Taken together Michael's accounts of the career of Athanasius and the behavior of the sons of Silvestros (both of

156 Michael the Syrian, Chronique, III, 13, IV, 485.

157 Ibid., II, 380, IV, 390.

158 Ibid., III, 13-14, IV, 485-6. 
which come from Dionysius of Tell Mahre) contain fairly obvious moralizing about the responsible and irresponsible use of wealth and the danger of displaying wealth too openly.

Rural property could include entire villages and was bought and sold. In the context of the foundation of Dara in the early sixth century, the emperor Anastasius paid the bishop, Thomas, in gold for a village that belonged to the Church. ${ }^{159}$ But an unscrupulous official might take advantage of his position to lower the price. For example Michael reports from Dionysius of Tell Mahre that ${ }^{\text {eAbd }}$ al-Ala increased the taxes on the people of Edessa, when Tahir appointed him over the city in 816 . He was evidently in charge of collecting taxes in the environs of Edessa as well and multiplied the charges on a village he coveted, that belonged to the Edessenes, until they were forced to sell it to him at a low price. Then he expelled the Edessenes from the village and settled members of his own tribe, the Banu Sulayman, there. ${ }^{160}$ Also from Dionysius is Michael's account of Ahmad ibn Abi Da'ud of the Banu Iyad in the early ninth century. When he coveted a village (probably in the Jazira), he charged taxes on it to the point that its owner had to sell it, and he bought it himself for a low price. He is said to have seized many villages that way. ${ }^{161}$

[43] Urban rental property was another source of income. The shops that Athanasius bar Gumaye owned at Edessa have already been mentioned. The income of the great church of Edessa came from inns, shops, and similar buildings that it owned. Michael says that most of this income went to pay the tribute owed by the Edessenes and that, in 829 or 830, the caliph al-Ma'mun freed them from it. ${ }^{162}$ Baths could also be lucrative. According to Michael (again from Dionysius) the rent (probably for a year) from a single bath at Samarra' under al-Mu'tasim amounted to 30,000 dirbams, while the monthly income from all the baths in the city was 300,000 dirhams. ${ }^{163}$

[44] Michael does have some unusual information about taxation. For instance, he reports that Christian farmers did not pay tribute at first under Arab rule. It was only under Mucawiya, in 669, that

\footnotetext{
159 Michael the Syrian, Chronique, II, 160, IV, 260.

160 Ibid., III, 35, IV, 499.

161 Ibid., III, 107, IV, 540-1.

162 Ibid., III, 74, IV, 523.

163 Ibid., III, 104, IV, 543.
} 
Abu l-Awar had the Christian farmers recorded for tribute throughout Syria. ${ }^{164}$ It would seem that the tribute imposed on cities in the terms of surrender at time of the conquest in the seventh century had not included the countryside in Syria. Cities were supposed to make a lump sum annual payment; the inhabitants could raise it anyway they liked. It was probably in the early eighth century that the people of Edessa lacked the means to pay part of the tribute they owed. So they borrowed 5,000 dinars from Athanasius bar Gumaye and repaid him later. ${ }^{165}$ Michael also reports that coins went out of circulation except among merchants in 772, because al-Manșur had collected all the gold and silver in his treasury. People resorted to grave-robbing to find gold and silver to pay their tribute. ${ }^{166}$

Although Michael notes the presence of merchants in the economy, he has precious little to say about commerce. He does refer to a market outside the wall of Amida, where workers brought wheat and wine in the early sixth century, ${ }^{167}$ and to a deacon named Damianus of the monastery of Mar Mari, who went to the village of 'Ufrai at the time of vintage to buy wheat. ${ }^{168} \mathrm{He}$ remarks that, when Nicephorus and ar-Rashid made peace in 803, the armies and peoples mingled and engaged in commerce. ${ }^{169}$ In 813 he mentions the house of a cotton merchant at Baghdad and that merchants were a source of wealth for the encampment of the Banu Tanukh near Aleppo. ${ }^{170} \mathrm{He}$ has the details about the exchange between the Nubians and the Arabs in Egypt, that was set up when the frontier was stabilized after the conquest of Egypt in the seventh century. The Nubian kings gave the king of the Arabs 360 "Moors" as slaves, monkeys, giraffes, elephant tusks, and tiger (?) skins each year, and the kings of the Arabs gave the Nubians wheat, olive oil, and cloth for precious clothing each year. What is valuable, and somewhat surprising, is that Michael says that

164 Ibid., II, 450, IV, 434.

165 Michael the Syrian, Chronique, II, 476, IV, 448.

166 Ibid., II, 526, IV, 476-7. This is also reported by the Chronicle of Zuqnin. See Chabot, Chronique de Denys, 147-8 [179-9]; Harrak, Chronicle of Zuqnin, 277-8.

167 Michael the Syrian, Chronique, II, 161, IV, 260.

168 Ibid., II, 448, IV, 431.

${ }^{169}$ Ibid., III, 16, IV, 488.

${ }^{170}$ Ibid., III, 30-1, IV, 497. 
this lasted until the disorders during the 'Abbasi civil war in the second decade of the ninth century. ${ }^{171}$

Michael has more to say about the vulnerability of merchants. He tells how merchants were pillaged at Nisibis by al-Walid the Haruri in 789, ${ }^{172}$ at Samosata by the rebel/brigand ${ }^{\mathbf{e}} \mathrm{Amr}$ in $812,{ }^{173}$ and at Antioch by the Byzantines, who attacked the city by sea in 838. ${ }^{174}$ Because pirates in Bahrayn prevented merchants or ships from India, China, and Persia from reaching Bașra, some 30,000 Bas rans attacked Bahrayn by ship in 825 only to be caught in a ford, where the Bahraynis attacked them in boats, killing them all. ${ }^{175}$ Ten years later, in 835, Zuțt rebels in lower 'Iraq pillaged and massacred merchants going to Baghdad from Bașra, India, and China. ${ }^{176}$ Mangshur, the son of Afshin's sister, began to pillage and kill merchants in Armenia in 841, but was executed himself soon afterwards. ${ }^{177}$ It is curious that all of this information is clustered between the late eighth and mid-ninth century, and, of course, it all comes from Dionysius of Tell Mahre. There is no similar information in Michael's Chronicle either before or after. Was Dionysius the only one among Michael's sources to be interested in such information, or were conditions really becoming more dangerous for merchants by the early ninth century? It is difficult to believe that merchants were robbed and killed only then.

Apart from the slave-merchants in Anatolia in 1176 noted above, the only other information Michael has about commerce in the twelfth century consists of a couple of references to caravans. During the winter of 1133-4 a caravan of approximately 400 Persian merchants, including four Christians, set out from Constantinople (presumably for Iran) and all perished in the snow. ${ }^{178}$ Michael also reports that, during the famine of 1176 in Jerusalem, Damascus, Aleppo, and the desert, caravans of Arabs

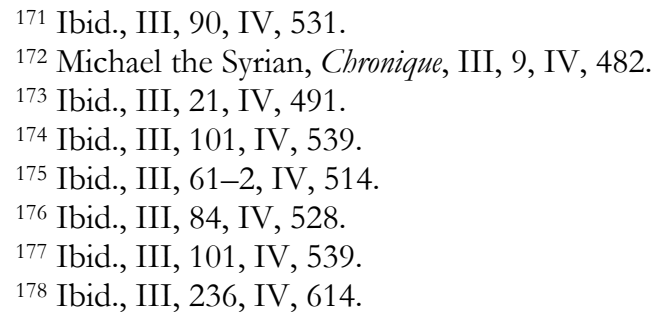


set out with their camels and imported wheat to Syria, without saying from whence they came. ${ }^{179}$

Taken altogether the economic information in Michael's Chronicle is overwhelmingly negative. Life was clearly hard and precarious. It was even harder when calamities converged on each other. For instance Michael says that, in addition to the famine caused by locusts between 803 and 808 , calamities were caused at the same time by taxes and tributes and by the scarcity of silver, which had been collected in the royal treasury. ${ }^{180}$ Part of the reason for this negative image, and for the value of his Chronicle, lies in the fact that he presents the point of view of the subject population. But there is also a bit of sensationalizing similar to the modern news media. What was worth reporting were the remarkable exceptions to normal expectations.

Almost all of Michael's economic information relates to the period from the sixth to the mid-ninth century and comes from John of Ephesus, Jacob of Edessa, and Dionysius of Tell Mahre or to the twelfth century during Michael's own lifetime. It can thus be treated as contemporary, although Michael appears to have been somewhat selective in drawing on earlier sources. Much of this information consists of isolated entries or is incidental to some other theme. Although it is usually intrinsically interesting and valuable, much of his incidental information needs to be contextualized and compared to that in other sources. Thus it is dangerous to draw conclusions about economic history from Michael alone.

\section{BIBLIOGRAPHY}

Barceló, M. "Les plagues de llagost a la Carpetània." Estudis d'Història Agrària, 1 (1978): 67-84.

Bedrosian, R. Sebeos' History. New York: Sources of the Armenian Tradition, 1985.

Brock, S.P. "A chronicle of disasters dated AD 716." In Palmer, A., ed. The Seventh Century in the West-Syrian Chronicles. Liverpool: Liverpool University Press, 1993.

Brock, S.P. "The Fenqitho of the Monastery of Mar Gabriel in Tur “Abdin." Ostkirchliche Studien, 28 (1979): 168-82.

${ }^{179}$ Ibid., III, 369, IV, 714.

180 Michael the Syrian, Chronique, III, 19, IV, 488. 
Cahen, Claude. "Fiscalité, propriété, antagonismes sociaux en HauteMésopotamie au temps des premiers 'Abbasides d'apres Denys de Tell-Mahré." Arabica, 1 (1954): 136-52.

Chabot, J.-B. Chronique de Denys de Tell-Mabré, Quatrieme Partie. Bibl. Éc. Hautes Études, 112. Paris: Bibliotheque de l'École, 1895.

Chabot, J.-B. Chronique de Michel le Syrien. Paris: E. Leroux, 1899; repr. Bruxelles: Culture et Civilisation, 1963.

Harrak, A. The Chronicle of Zuqnin, Parts III and IV, A.D. 488-775. Toronto: Pontifical Institute of Mediaeval Studies, 1999.

Kedar, B. "The Arab Conquests and Agriculture: a seventh-century apocalypse, satellite imagery and palynology." Asian and African Studies, 19 (1985): 1-15.

Khalidi, T. "Tribal Settlement and Patterns of Land Tenure in Early Medieval Palestine." In Khalidi, T., ed. Land Tenure and Social Transformation in the Middle East. Beirut: American University of Beirut, 1984.

Martin, P. Chronique de Josue le Stylite, Abhandlungen für die Kunde des Morgenlandes, VI. Band, No. 1. Leipzig: Deutschen Morgenländischen Gesellschaft, 1876.

Procopius. History of the Wars, tr. H.B. Dewing. London: William Heinemann / New York: The Macmillan Co., 1914; Harvard University Press, 1914; repr. 1996.

Taha, 'A.D. The Muslim Conquest and Settlement of North Africa and Spain. London and New York: Routledge, 1989.

Thomson, R.W., The Armenian History attributed to Sebeos. Liverpool: Liverpool University Press, 1999.

Uvarov, B.P. Locusts and Grasshoppers. London: The Imperial bureau of entomology, 1928.

Wallis Budge, E.A., The Book of the Governors. London: K. Paul, Trench, Trübner \& co. ltd., 1893. 